\title{
Export Behavior, Export Performance and International Marketing Strategy on Export Promotion of Small and Medium Enterprises: An International Trade Perspective in Developing Countries
}

\author{
Sintayehu Assefa(PhD Candidate) Professor Dhason Antony \\ School of Post Graduate Studies Department of Management, Arba Minch University
}

\begin{abstract}
The aim of this Doctoral Seminar-I is to examine why the majority of SMEs in the developing countries like Ethiopia remain focused on the domestic market, while few choose to sell a proportion of their goods abroad, even though they face similar market conditions and operate in the same location. A variety of explanations to this problem exist in the literature examining the export promotion strategy of SMEs. Following the recognition of a gap in international marketing strategy such as: standardization and adaption, managerial determinants and export behavior including expansion and involvement based on the literature studies, this Doctoral Seminar-I seeks to shed light on the issue from the Ethiopian context. The seminar proposes an integrated theoretical framework, developed from the analyses of the extant literature review, to address an explanation why some SMEs export do not succeed to achieve the exporting of their products in the context of developing countries like Ethiopia. The proposed framework consists of a synthesized integration of the following theoretical perspectives: the resource-based view of the firm; stage theory; network theory, international entrepreneurship theory; and contingency theory which mostly applicable in the context of SMEs. Here, the key assumptions underlying the integrated framework that SMEs export behaviour represents a complex event, and therefore no single theoretical framework is robust enough to explain the phenomenon in detail. In addition, as none of the theoretical frameworks are without weakness it is argued their integration offsets the weaknesses of each, thereby offering a deeper explanation of the factors underlying export behaviour, international marketing strategy and managerial determinants.
\end{abstract}

Keywords: Export promotion, Internationalization, Export behavior, Ethiopia

DOI: $10.7176 / \mathrm{JEP} / 10-16-06$

Publication date: June $30^{\text {th }} 2019$

\subsection{Introduction to the study}

Small and medium enterprises (SMEs) play a pivotal role in generating economic well-being for most countries (Karandeniz and Gocer, 2007; Moen and Servais, 2012) especially as they represent the main part of the industrial base. Numerous studies draw attention upon the direct link between internationalization and increased SMEs performance. Here, proactive internationalization reinforces growth, enhances competitiveness as well as supports the long term sustainability of companies (European Commission, 2017).

In this dynamic and turbulent environment, the internationalization of small and medium-sized businesses (SMEs) has flourished in recent times across the world (Orser et al., 2008). And in this regard Small and Medium Enterprises (SMEs) have played and continue to play significant roles in the growth, development and industrialization of developing countries. Accordingly, most developing countries have formulated and implemented a wide variety of SMEs development strategies in order to support the growth of the sector, thereby transforming economies and generating substantial employment opportunities (World Bank, 2018).

As far as the role of SMEs is concerned, Schlogl (2004) stated that these firms dominate both developed and developing economies in terms of employment and number of companies, yet their full potential remains unexploited extensively and these trends need to be changed. The ability of smaller firms to create jobs is clearly a major attraction for governments in the short term. SMEs must be encouraged and supported to flourish. This is important so that economic objectives (economic growth and development, favorable balance of trade and payment and employment) and social objectives (poverty alleviation and improving standards of living) can be realized. Governments must respond to the needs of SMEs as they form an important component of the economy (Singh and Mahadevan, 2012).

A study made by Leonidou et al. (2011) revealed that export provides one of the most common routes to enter international markets spurred by its greater structural and strategic flexibility compared to alternatives such as foreign direct investment and international aid (Leonidou et al., 2011).

When the importance of SME internationalization with regard to Africa is concerned, according to Rankin et al. (2016) has been recognized in Sub-Saharan Africa and Africa in general. In Sub-Saharan Africa, the researchers argue that most small and medium enterprises reside in the domestic market, and therefore, without export involvement, it will be unlikely to propel firms into growth. In Africa, in general, Rankin et al. (2016), 
Kuada (2017) and Wolf (2017) reported that the overall international market of the continent is in its infant stage to propel firms' growth. Therefore, the issue of export promotion is getting a prior concern in bringing growth for SMEs.

The Doctoral Seminar - I built around the theory on stages of internationalization, to reflect the fact that SMEs in the new evolving digital environment, are still in need of acquiring export market knowledge throughout the different stages of the internationalization process through secondary sources. Export marketknowledge as a firm resource boosts its competitive position and in turn to increased commitment to the export operation. On a theoretical level, a perceived usefulness construct for international trade points will be developed which paves the way to empirical tests of the different recommendations in the export promotion literature.

\subsection{Statement of the problem}

Giles and Williams (2010) argue that countries in Africa and Latin America mainly followed an import substitution strategy and it prevented them from attaining the growth through internationalization exercising export promotion.

Small and Medium Enterprise (SMEs) sector according to EEA (2017) confirmed that SMEs has emerged as a highly vibrant and dynamic sector of the Ethiopian economy over the last decade. SMEs not only play a crucial role in providing employment opportunities but also contribute enormously to the socio-economic development of the country, notably in their role as catalysts for the transition to an industrial society. SMEs are viewed as seedbeds for the development of medium and large enterprises. It is reported that there are approximately 800,000 SMEs across the country (EEA, 2017).

In the context of Ethiopian, a study made by Andualem (2007) on challenges and prospects of Export Trade in Ethiopia and the result disclosed that quality problems, inefficient management of exporters, inefficient promotion of the export sector, and low performance of export processing are the main findings of the study but failed to integrate theories of internationalization, export behavior and international marketing strategy and in this context, the study explored other additional challenges in eport promotion through incorporating the export behavior and international marketing strategy (Andualem, 2007).

Ethiopia being one of the developing countries in the Sub-Saharan Africa has implemented a number of trade and fiscal reforms as a way to encourage raising export by manufacturing firms (Gebrewahid, 2017). In Ethiopia, as far as the researcher's knowledge is concerned, no evidenced literature are available on the topic under study: "Export Behavior, Export Performance and International Marketing Strategy of Export Promotion of SMEs: An International Trade Perspective in Developing Countries". Therefore, despite the previous studies provide useful knowledge, this Doctoral Seminar-I will bring more insightful picture of the subject from the export barriers and its consequence on the export competitiveness perspectives.

\subsection{Objectives of the seminar}

The general objectives of the study is to assess the Export Behavior, Export Performance and International Marketing Strategy on Export Promotion of SMEs: An International Trade Perspective in Developing Countries.

Specifically, this Doctoral Seminar-I addresses the following specific objectives in line with the general objective

1. To undertake an extensive literature review on export behaviour through managerial characteristics and perception in exporting.

2. To identify the factors that influence the export performance determinants in SMEs.

3. To examine the impact of standardization/adaptation of the overall international marketing strategy on export performance and satisfaction.

\subsection{Significance of the Seminar}

The purpose of this Doctoral Seminar-I is to address the current low involvement in manufacturing export of SMEs in Ethiopia. This Doctoral Seminar-I will seek to ascertain exporting SMEs behaviour of internationalization in Ethiopia. By applying the proposed conceptual framework, the study intends to make a contribution to the field, using new insights on the strategy of export promotion in Ethiopia. Currently, the lack of studies concerning the export behaviour of SMEs in Africa (e.g. Ethiopia) inhibits understanding in this area. In addition, identifying the main firm-level capacity factors, which significantly predict small business export decisions and export performance, will lead to an efficient utilization of resources. Moreover, public policy makers can draw on the outcomes of the study to aid their decisions on which firms need export assistance in order to make a contribution to the overall growth and prosperity of developing countries like Ethiopia. The findings in the study, thus, will help to fill the gap in the export promotion strategy literature regarding the internationalization of manufacturing performance. 


\section{Theory and Review of Literature}

This part of a literature review starts by introducing the historical background of the internationalization phenomenon in the context of export promotion. In this regard, an overview of the extant internationalization theories follows (i.e. the classical theories and the generally accepted internationalization theories). After that an examination of the generally accepted internationalization theories and views like the resource-based view, stage theory, network theory and international entrepreneurship theory, developed to address the objectives of Doctoral Seminar-I outlined in the objectives of the study.

\subsection{Theories of Internationalization}

Though this Doctoral Seminar-I do not seek to evaluate the extant theories of the internationalization research field as its main purpose but rather it will provide a general overview of the major theories in the field of internationalization.

\subsection{Dimensions of Internationalization Theories}

Mtigwe (2006) classified internationalization theories in the field into four dimensions. Mtigwe's dimensions comprise: (1) the classical internationalization theories (i.e. the theory of absolute advantage; the theory of comparative advantage; and the Heckscher-Ohlin factor proportion theory); (2) the early market imperfection theories (i.e. the foreign direct investment theory and international product life cycle theory); (3) the later market imperfection theories (i.e. the portfolio theory; the internalization theory; the eclectic theory; and the resources advantage theory); and (4) the internationalization theories (i.e. the incremental theories; the network theory; and the international entrepreneurship theory) (Ruzzier et al, 2006).

According to Rialp and Knight (2015), the gradual approach to the internationalization phenomenon, particularly appropriate for studying SMEs, conceptualizes the internationalization of the firm as a learning process based on the accumulation of experimental foreign market knowledge. When the theoretical knowledge with regard to internationalization is concerned, both the Uppsala internationalization model and innovation related model posit that internationalization is an incremental process based on various stages that determine changes in the behavior and commitment of the managers which are ultimately reflected on the international orientation of the firm. For enhancing the understanding of the internationalization process of small and medium firms, the network theory has also been considered (Rialp and Knight (2015).

In another dimension of internationalization, the international activity appears to be largely driven by network relationships which generally stem in SMEs from manager's personal contacts in foreign market (Anderson, 2006). Besides, managerial and organizational experience in international business could be enhanced by the international experience acquired by other companies with which a network contact is maintained (Rankaduwa, 2017).

The Resource Based View (RBV) is one theory of internationalization with the view that firm resources are sources of competitive advantages. Thus, an important implication of the RBV is that a wide range of individual, social and organizational phenomenon within the firms might be sources of sustained competitive advantage (Barney, 1991). Moreover, the significance attained by the RBV in the 1980s has led academics to base their arguments on intangible resources, which may be understood to be those assets, knowhow and/or skills which are difficult to formalize and be reproduced by competitors. Hence, these intangible resources become strategic assets, generating a competitive advantage for the firm, and finally generating benefits (Daniel etal, 2017). Further developments relate this theory to the international context, suggesting that those firms which present unique bundles and combinations of resources stocks may have a higher proclivity towards internationalization.

According to Hall and Cook (2009) the contingency approaches looks for a balance between international marketing strategy standardization and adaptation. It posits that no strategy is strictly better than the other. Standardization or adaptation is not a dichotomous decision, but rather a matter of degree as marketing strategies are contingent upon internal and external factors (Crick and Spence, 2015). Therefore, this Seminar also relies on the contingent perspective which allows for various degrees of standardization which are contingent on the internal organizational characteristics and the environmental forces.

With regard to stage theory as described by Johanson and Vahlne (1977) later built on Johanson and Wiedersheim (1975) work and confirmed the stages of firms' internationalization behaviour. They maintained that the gradual progression is driven by a lack of prior experiential knowledge of the foreign market. In addition, the above scholars contend that the gradual development of export behaviour by the firm also reflects its lack of appropriate resources to meet the demands of international markets.

Following these assumptions, implicitly, the main explanatory variables of the stage theory: (1) the firm's size; (2) firm's age; (3) the age of its owner-manager; (4) its previous experience in the domestic market; (5) its prior export experiential knowledge; (6) the nature of the geographical and psychological situation of the country it wants to export to; (7) its own efforts at resource development for export business; (8) gradual export development and (9) the influence of its internal environment lead the firm to respond positively to the triggers 
of export initiation and facilitate its capacity to meet export orders.

Network theory, on the other hand, challenges this premise and argues that internationalization is a collaborative activity that makes it easier (e.g. in terms of the cost, time, resources and pace) for a firm to enter the international market than if it was acting alone (Johanson and Mattson, 1988).

With regard to the SME internationalization, the basic assumption of IE theory is that certain unique entrepreneurial behavioral characteristics cause some SME to enter the international market at their inception. In addition, the framework implies that the time to enter the international market, the nature of entry mode to be used, the choice of export market to be selected and subsequent development of the export business are driven by exceptional entrepreneurial factors to spot export business opportunities. In relation to the problem statement this Doctoral Seminar-I seeks to investigate, the IE assumption implies that it is the possession of these unique entrepreneurial characteristics that determines why some owner-manager-entrepreneurs enter the foreign market while similar others remain focus on the domestic market, although they may all be operating in the same industry and location, and face the same market conditions (Mc Dougall et al., 1994).

\subsection{Export promotion and performance}

According to UNESCAP (2017) defines export promotion as a set of actions which seek to promote exports of a country's existing production. Its basic goal is to encourage increased sales of products which are currently available for exports. Export promotion is an alternative development strategy that is much better than its counterpart, import substitution. On one hand, import substitution aims at developing infant industries. On the other, export, promotion enables a country to have access to international markets (Rankaduwa, 2017).

In today's dynamic and turbulent environment, countries have generally decided to abandon import substitution strategy in favor of export promotion. Here, the emphasis is generally on the openness in both local and international markets. Such efforts have lead to efficient use of available resources and attainment of higher productivity levels (Singh and Mahadevan, 2012).

Different scholars argued that drivers on internationalization are classified as internal and external factors. According to Reid (1981) the determinants of internationalization in relation to export performance are classified into main groups, namely, determinants internal to the firm and determinants that are external. When internal determinants concerned, it conceivably are subject to management's discrete decision-making power that can be classified into four general categories such as firm characteristics and competencies (firm size, firm age, firm technology, and firm international competence), managerial characteristics (skills of top management, training of managers, export experience), management support (export commitment, management's attitude and perceptions, proactive export motivation), and export strategy (general export strategy, product quality, product line, product adaptation, price adaptation, dealer support and promotion adaptation).

As far as the external factors that drive internationalization with regard to export performance concerned, the external determinants are derived from external environmental factors and which the firm does not directly control (uncontrollable factors). Different literature identified three types of external determinants of export performance including industry characteristics (industry's technological intensity, industry's level of instability), foreign market characteristics (export market attractiveness, export market competitiveness, export market barriers), and domestic market characteristics (domestic market attractiveness).

\subsection{Conceptual framework}

With regard to export promotion, a review of the extant theoretical assumptions in the field (the resource-based view and the process theory), coupled with their corresponding empirical findings shed much light on the SMEs export promotion. It is argued that the determinants of export decisions for the SMEs appear to consist of external and internal factors, but it is the influence of the internal resource capacity which significantly facilitates the export promotion of the SME rather than the external factors (Westhead et al., 2008; Ibeh, 2009; Ibeh and Wheeler, 2012; Sousa et al., 2013; Williams, 2014; Lages et al., 2015). The proposed integrated theoretical framework applied in this study consists of combining the resource-based view, the stage theory, the network theory and the international entrepreneurship theory. 
Figure 2.1. Integrated conceptual framework: Author's design based from the export promotion literature

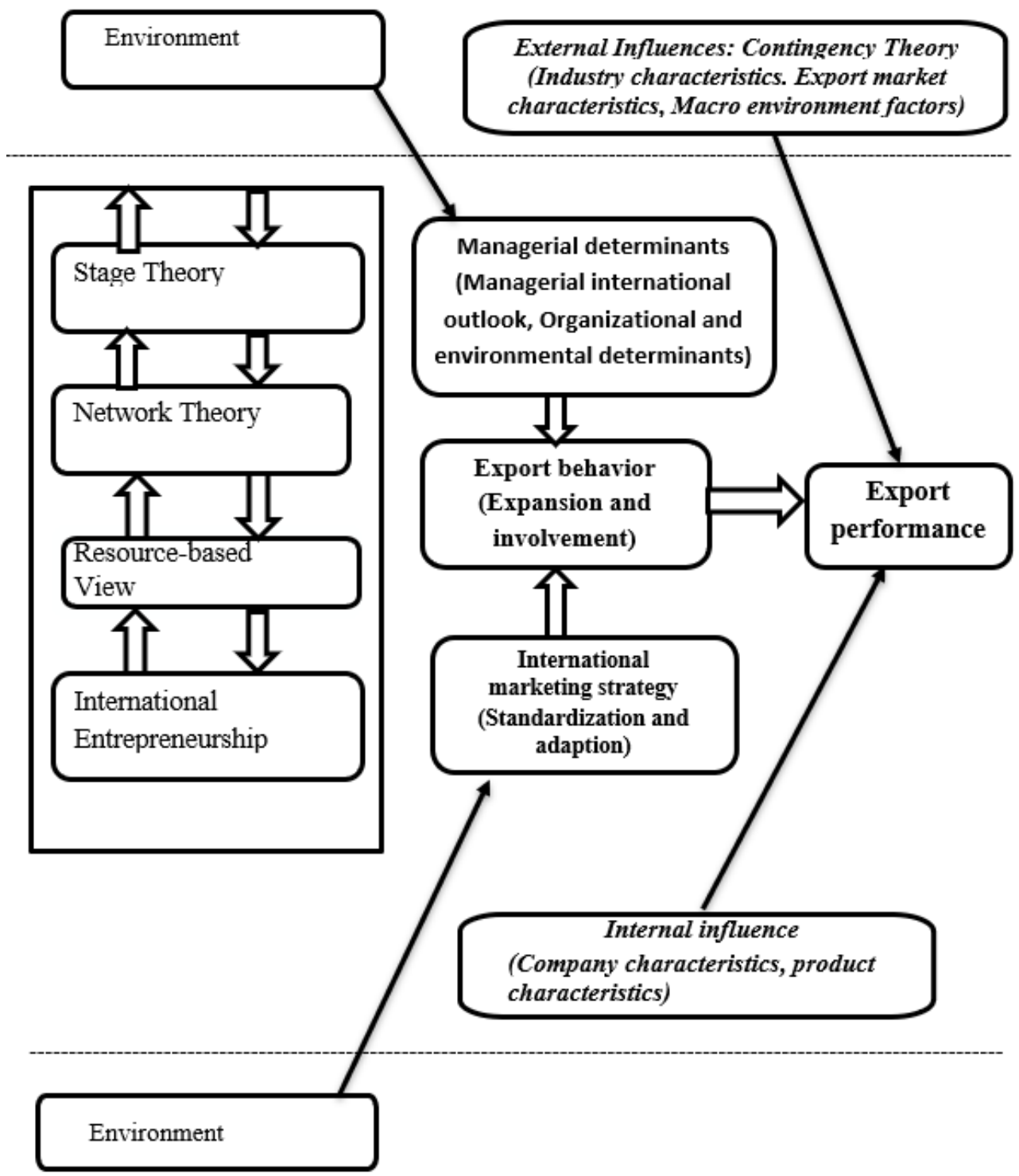

Source: Own development (2019)

The above integrated framework in Figure 2.1. is based on the eleven generally accepted internationalization theories including, the resource-based view (RBV), stage theory, network theory and international entrepreneurship which will offer the best and most detailed explanation of export promotion activities of SMEs than others (e.g. product life cycle theory, internationalization and transaction cost theory) which the different literatures also confirmed including (Ruzzier et al., 2006; Johanson and Vahlne, 2009; Johanson and Vahlne, 2010).

The justification for the proposed model is that, though some studies (e.g., Moen and Servais, 2012) apply a single theoretical framework to analyze the SME's internationalization or export promotion activities. This Doctoral Seminar-I builds on the argument that the internationalization or export behaviour of the SME signifies a complex phenomenon that cannot be fully accounted for by any single theoretical framework. As a result, this Seminar builds on the work of researchers (e.g. Coviello and Martin, 2009; Crick and Spence, 2015; Coviello and Martin, 2016; Rialp et al., 2015; Hall and Cook, 2009) who apply more than one theoretical framework and thus adopt a similar line of argument in their respective studies on the topic. Moreover, it is stressed that an integrated theoretical framework offers greater potential to explain the SMEs' export promotion behavior than a single theoretical framework.

\section{Empirical literature on export promotion}

Several of the early empirical Export promotion of Small and Medium Enterprises with regard to an international trade perspective articles have been survey and exploratory research studies that focus on developing a theoretical development of export promotion (Giles and Williams, 2010; Menna, 2013; Nhema and Zeleza, 2008; 
Awokuse, 2003; Abor, J. and Quartey, 2010; Maneschold, 2008; Mah, 2010; Yang, 2018) (see Table 4.1 for a summary of empirical research on export promotion in an international trade literatures). Though there are some differences in their samples and research questions, each of these survey and exploratory studies have employed similar types of procedures to make findings on strategy of export promotion.

To state some empirical review, in most industrialized countries, researchers have supported the importance of export manufacturing among SMEs in developing countries context. A study made by Zang and Baimbridge (2012) analyzed the relationship between exports, imports, and economic growth in Japan and South Korea, and confirmed the ELG hypothesis in Japan while economic growth negatively affected exports in Korea. In another interrelated research made by Abor and Quartey (2010) use samples from five countries in Sub-Saharan Africa (SSA) and also supported the importance business and growth hypothesis. Similarly, Nyikam (2004) conducted a similar study of 21 countries in SSA and found that country-specific support for the hypothesis.

Table 4.1: Summary of the Empirical on the study subject

\begin{tabular}{|c|c|c|c|}
\hline Authors & $\begin{array}{l}\text { Objective of the } \\
\text { study }\end{array}$ & Empirical Methodology & Key findings \\
\hline $\begin{array}{l}\text { Awokuse } \\
(2003)\end{array}$ & $\begin{array}{l}\text { To test the validity of } \\
\text { the export-led growth } \\
\text { hypothesis with } \\
\text { respect to Canada }\end{array}$ & $\begin{array}{l}\text { Canadian real GDP, real } \\
\text { exports, and real terms of } \\
\text { trade, manufacturing } \\
\text { employment as a proxy for } \\
\text { labor, gross capital } \\
\text { formation as a proxy for } \\
\text { capital and industrial } \\
\text { production index for all } \\
\text { industrialized countries as } \\
\text { a proxy for foreign output } \\
\text { shock }\end{array}$ & $\begin{array}{l}\text { The study found that there was strong } \\
\text { statistically significant which suggests that } \\
\text { real exports Granger caused real GDP in } \\
\text { Canada at a } 1 \% \text { level of significance }\end{array}$ \\
\hline $\begin{array}{l}\text { Andualem } \\
(2007)\end{array}$ & $\begin{array}{l}\text { To assess and evaluate } \\
\text { the } \\
\text { level of performance, } \\
\text { the challenges and } \\
\text { prospects of export } \\
\text { trade in } \\
\text { Ethiopia. }\end{array}$ & $\begin{array}{l}\text { A causal type of research } \\
\text { design was used }\end{array}$ & $\begin{array}{l}\text { The main findings of the study related } \\
\text { with Quality problems, inefficient } \\
\text { management of exporters, inefficient } \\
\text { promotion of the export sector, and low } \\
\text { performance of export processing. }\end{array}$ \\
\hline $\begin{array}{l}\text { Maneschold } \\
(2008)\end{array}$ & $\begin{array}{l}\text { To test the validity of } \\
\text { the export-led growth } \\
\text { hypothesis in } \\
\text { respect of Argentina, } \\
\text { Brazil and Mexico }\end{array}$ & $\begin{array}{l}\text { GDP at constant prices and } \\
\text { exports of goods and } \\
\text { services }\end{array}$ & $\begin{array}{l}\text { It revealed an unidirectional short run } \\
\text { relationship from export to GDP but the } \\
\text { Export-GDP nexus was by nature a } \\
\text { relationship that was long run }\end{array}$ \\
\hline $\begin{array}{l}\text { Yang } \\
(2008)\end{array}$ & $\begin{array}{l}\text { To examine episodes } \\
\text { which were used as a } \\
\text { proxy for exports in } \\
\text { driving growth and } \\
\text { those used as a proxy } \\
\text { of growth in driving } \\
\text { exports }\end{array}$ & $\begin{array}{l}\text { The study used data on } 44 \\
\text { countries over the period } \\
1958-2004\end{array}$ & $\begin{array}{l}\text { The study found that among the episodes } \\
\text { that were characterized by high GDP } \\
\text { growth, about half were supported by } \\
\text { export-led hypothesis and } \\
\text { most likely, the other half was likely led } \\
\text { by productivity improvement in non- } \\
\text { tradable sector }\end{array}$ \\
\hline $\begin{array}{l}\text { Giles and } \\
\text { Williams } \\
(2010)\end{array}$ & $\begin{array}{l}\text { To explore the } \\
\text { correlation between } \\
\text { exports and economic } \\
\text { growth }\end{array}$ & $\begin{array}{l}\text { aggregate production using } \\
\text { annual data }\end{array}$ & $\begin{array}{l}\text { expanding or contracting } \\
\text { foreign trade can have an impact on } \\
\text { growth and that the relationship between } \\
\text { foreign trade and growth is somewhat } \\
\text { varied and complex }\end{array}$ \\
\hline Mah (2010) & $\begin{array}{l}\text { To test whether export } \\
\text { promotion measures } \\
\text { led to export } \\
\text { expansion and used } \\
\text { the export pattern of } \\
\text { Korea }\end{array}$ & Export data & $\begin{array}{l}\text { The study found that during the period of } \\
\text { rapid economic growth, the Korean } \\
\text { authorities gave tax and financial } \\
\text { incentives and established export } \\
\text { promotion agencies }\end{array}$ \\
\hline
\end{tabular}




\begin{tabular}{|c|c|c|c|}
\hline Authors & $\begin{array}{l}\text { Objective of the } \\
\text { study }\end{array}$ & Empirical Methodology & Key findings \\
\hline $\begin{array}{l}\text { Muhammad } \\
\text { et. Al } \\
(2012)\end{array}$ & $\begin{array}{l}\text { To examine } \\
\text { empirically the impact } \\
\text { of various } \\
\text { determinants on } \\
\text { exports in Pakistan }\end{array}$ & $\begin{array}{l}\text { Secondary data over the } \\
\text { period from } 1981-2011 \text { on } \\
\text { Gross domestic product, } \\
\text { Foreign Direct Investment, } \\
\text { Nominal Exchange rate, } \\
\text { Indirect Taxes, Industry } \\
\text { value added and Gross } \\
\text { National Savings }\end{array}$ & $\begin{array}{l}\text { The results show positive and statistically } \\
\text { significant impacts of explanatory } \\
\text { variables such as world } \\
\text { income, industry value added, indirect } \\
\text { taxes, exchange rate and saving on exports } \\
\text { of Pakistan during the study period }\end{array}$ \\
\hline $\begin{array}{l}\text { Menna } \\
(2013)\end{array}$ & $\begin{array}{l}\text { To investigate the } \\
\text { factors that affect the } \\
\text { performance of Small } \\
\text { and Medium } \\
\text { Enterprises (SMEs) in } \\
\text { the manufacturing } \\
\text { sector of Cairo, Egypt }\end{array}$ & $\begin{array}{l}\text { A personal interview on } 50 \\
\text { SMEs in Cairo Egypt }\end{array}$ & $\begin{array}{l}\text { The finding suggests that managerial } \\
\text { aspects which are in short supply have } \\
\text { negative effects on the performance of } \\
\text { SMEs in the manufacturing sector. }\end{array}$ \\
\hline $\begin{array}{l}\text { Abeh } \\
(2017)\end{array}$ & $\begin{array}{l}\text { To evaluate the } \\
\text { challenges and } \\
\text { prospects of SMEs in } \\
\text { a sustainable and } \\
\text { competitive advantage } \\
\text { or disadvantage of its } \\
\text { growing importance } \\
\text { in Nigerian economy }\end{array}$ & $\begin{array}{l}\text { The } \\
\text { research design was a a } \\
\text { survey as much as it is } \\
\text { descriptive research design }\end{array}$ & $\begin{array}{l}\text { The study it was found that the challenges } \\
\text { of SMEs significantly affect the growth } \\
\text { and development of SMEs. Government } \\
\text { efforts were found to significantly affect } \\
\text { the growth and development of SMEs in } \\
\text { Nigeria. However, the prospects of SMEs } \\
\text { in Nigeria do significantly affect its } \\
\text { growth and development. And there were } \\
\text { no significant differences in the opinions } \\
\text { of the respondents based on their age and } \\
\text { gender. }\end{array}$ \\
\hline $\begin{array}{l}\text { Daniel et. } \\
\text { Al (2017) }\end{array}$ & $\begin{array}{l}\text { To examine the effect } \\
\text { of export promotion } \\
\text { programs on export } \\
\text { performance. }\end{array}$ & $\begin{array}{l}\text { The list of manufacturing } \\
\text { exporters was obtained } \\
\text { from the Ghana Export } \\
\text { Promotion Authority, and } \\
\text { the convenience and } \\
\text { snowballing approach }\end{array}$ & $\begin{array}{l}\text { The findings of this study } \\
\text { show that the programs that have a strong } \\
\text { positive relationship with export } \\
\text { performance are trade fairs, } \\
\text { foreign offices and tax and financial } \\
\text { incentives. }\end{array}$ \\
\hline $\begin{array}{l}\text { Gebrewahid } \\
(2017)\end{array}$ & $\begin{array}{l}\text { To investigate the } \\
\text { export barriers and } \\
\text { export } \\
\text { competitiveness of the } \\
\text { Ethiopian Leather } \\
\text { Footwear } \\
\text { manufacturing firms } \\
\text { in particular and the } \\
\text { industry in general }\end{array}$ & $\begin{array}{l}\text { Purposively, } 100 \\
\text { respondents were selected } \\
\text { from } 15 \text { exporting firms in } \\
\text { the leather industry }\end{array}$ & $\begin{array}{l}\text { The finding disclosed that with different } \\
\text { perceived intensity, all the export barriers } \\
\text { such as government policy, human } \\
\text { resource, financial, product quality, } \\
\text { marketing knowledge and information, } \\
\text { competition barriers are important in } \\
\text { impeding the export competitiveness of } \\
\text { the industry }\end{array}$ \\
\hline $\begin{array}{l}\text { Sisay, } \quad \text { M } \\
(2018)\end{array}$ & $\begin{array}{l}\text { Assessment of } \\
\text { Challenges in Export } \\
\text { Marketing: The Case } \\
\text { of } \\
\text { Vegetable and Fruit } \\
\text { Commercial Growers }\end{array}$ & $\begin{array}{l}\text { The purpose of the study } \\
\text { was to assess export } \\
\text { marketing challenges of } \\
\text { Ethiopian vegetable and } \\
\text { fruit commercial growers. }\end{array}$ & $\begin{array}{l}\text { The study found that management } \\
\text { commitment problem; technological } \\
\text { advancement problem; financial; lack of } \\
\text { accessible transport system; low } \\
\text { awareness of stakeholders; seasonality of } \\
\text { Ethiopian supply; shortage of cargo; } \\
\text { shortage of infrastructure; government } \\
\text { bureaucracy; lack of potential markets; } \\
\text { and shortage of inputs were identified as } \\
\text { problems for the vegetable and fruit } \\
\text { export. }\end{array}$ \\
\hline
\end{tabular}

\section{Concluding remarks}

With regard to the exporting behaviour, the review unravels the general theoretical frameworks that predict the behaviour of the exporting firm. Among these theoretical frameworks, not all are appropriate for application to the SMEs, and only four are proposed for integration to address the research questions behind this Doctoral 
Seminar I. This review in this regard identified managerial, organizational and environmental determinants which will be tested in the research study in near future. In the context of export behavior, managerial characteristics and managerial perceptions are identified as a variable and finally with international marketing strategy, the overall standardization/adaptation including factors like product, promotion, price and distribution strategy on export performance and satisfaction will be analyzed in future work.

As a result, this Doctoral Seminar-I will contribute to filling this gap in the field specifically in export promotion with regard to export behavior, export performance and international marketing strategy in SMEs in developing countries context.

\section{References}

1. Abeh, O. (2017). The Problems and Prospects of Small and Medium Scale Enterprises (SMEs) Growth and Development in Nigeria: A Study of Selected SMEs in Delta State. International Journal of Scientific Research in Education, 10(3), 278-294.

2. Abor, J. and Quartey, P. (2010): "Issues in SMEs Development in Ghana and South Africa", International Research Journal of Finance and Economics, 39, 218-228.

3. Andualem Debas. (2007): Assessment of the Level of Performance, Challenges and Prospects of Export Trade in Ethiopia: A Management Perspective. Ethiopian Economic Association (EEA) proceedings of the second international conference on the Ethiopian Economy. Addis Ababa, Ethiopia: EEA.

4. Awokuse (2003): Is the export-led growth hypothesis valid for Canada? Canadian journal of economics, $36(1): 126-136$.

5. Barney, J. B. (1991): "Firms Resource and Sustained Competitive Advantage", Journal of Management, 17, 1, 99-120.

6. Coviello, N. E. \& Martin, K. A.-M. (2016): "Internationalization of Services SMEs: An Integrated Perspective from the Engineering Consulting Sector", Journal of Marketing Management, 7,5 40-69.

7. Crick, D. and Spence, M. (2015): "The Internationalization of 'High Performing' UK High-Tech SMEs: A Study of Planned and Unplanned Strategies", International Business Review, 14, 167-185.

8. Daniel M. Quaye, Kwame Ntim Sekyere, George Acheampong, (2017): "Export promotion programmes and export performance: A study of selected SMEs in the manufacturing sector of Ghana", Review of International Business and Strategy, Vol. 27 Issue: 4, pp.466-483

9. EEA (2017): Small and Micro Enterprises (SMEs) Development in Ethiopia: Policies, Performances, Constraints and Prospects.

10. European Commission (2017): Supporting the internationalization of SMEs: Final report of the Expert Group, Enterprise and Industry.

11. Gebrewahid, Gebreyohannes Gebreslassie, (2017): "Export Barriers and Competitiveness of Small and Medium-sized Enterprise in Developing Countries: Case study in Ethiopian Leather Footwear Manufacturing Firms". International Conference on African Development Archives. 133.

12. Giles, J. A. and Williams, C. L. (2010): Export-led growth: a survey of empirical literature and some noncausality results part 1. http:/ideas.repec.org/p/vic/vicewp/0001.html Date of access: 20 May. 2018.

13. Hall, G. and Cook, M. (2009): "The Relative Importance of Human Product Resources in Influencing the Export Propensity of Small UK's Firms", International Journal of Entrepreneurship \& Innovation Management, 10, 1, 71-87.

14. Ibeh, K.I.N. (2009): "Towards a Greater Level of International Entrepreneurship among Smaller Agribusiness Firms: Resource Levers and Strategic Options”, Management International Review, 45, 3, 5981.

15. Ibeh, K.I.N. and Wheeler, C. N. (2012): “A Resource Centered Interpretation of Export Performance", International Entrepreneurship and Management Journal, 1, 4, pp.539- 556.

16. Johanson, J. and Mattsson, L.-G. (1988): "Internationalisation in Industrial Systems - A Network Approach: In N. Hood and J.-E. Vahlne (eds), Strategies in Global Competition. Croom Helm, London, pp.287-314.

17. Johanson, J. and Vahlne, J.-E. (1977): "The Internationalisation Process of the Firm - A Model of Knowledge Development and Increasing Foreign Market Commitment", Journal of International Business Studies, Spring/Summer, 23-32.

18. Johanson and Vahlne, J-E. (2009): "The Uppsala Internationalization Process Model Revisited: From Liability of Foreignness to Liability of Outsidership", Journal of International Business Studies, 40, 14111431.

19. Johanson and Valhlne, J-E. (2010): "Internationalization as An Entrepreneurial Process", Journal of international Entrepreneurship, 8, 4, 343-370.

20. Johanson, J. and Wiederscheim-Paul, F. (1975): "The Internationalization of the Firm - four Swedish cases", Journal of Management Studies, 12, 3, 305-22.

21. Karadeniz, E and Gocer, K. (2007): Internationalization of small firms: A case study of Turkish SMEs. 
European Business Review, 19(50, 387-403.

22. Kuada, J. (2017): "Internationalization, Regionalization and Africa's Economic Growth Strategies", Journal of Business and Economic Research, 2, 1, 92-114.

23. Lages, L. F., Silva, G. and Styles, C. (2015): "Relationship Capabilities, Quality and Innovation as Determinants of Export Performance", Journal of International Marketing, 17, 4, 47-70.

24. Leonidou, L. C. (2014): "An Analysis of the Barriers Hindering Small Business Export Development", Journal of Small Business Management, 42, 3, 279-302.

25. McDougall, P. P., Shane, S. and Oviatt, B. M. (1994): "Explaining the Formation of International New Ventures: Limits of Theories from International Business Research", Journal of Business Venturing, 9, 6, 469-487.

26. Maneschold P. (2008): A note on the export led growth hypothesis: a time series approach. Cuadornos de economia, 45:293-302.

27. Menna Allah Ahmed Fouad. (2013): Factors affecting the performance of SMEs in the manufacturing sector of Cairo, Egypt. International Journl of Business and management Studies Vol 5, No 2, 2013 ISSN: 13098047.

28. Moen, S and Servais, P. (2012):'Born Global or Gradual Global? Examining the Export Behaviour of Small and Medium-Sized Enterprises", Journal of International Marketing, 10, 3, 49-72.

29. Mtigwe, B. (2006): "Theoretical Milestones in International Business: The Journey to International Entrepreneurship Theory", Journal of International Entrepreneurship, 4, 1, 5-25.

30. Muhammad Nadeem, Muhammad Azam and Rabiul Islam, (2012): An Investigation of the Various Factors Influence on Exports. Global Journal of Management and Business Research Volume 12 Issue 19 Version 1.0 ISSN: 2249-4588.

31. Nhema, A. and Zeleza, P. T. (2008): The resolution of African conflict, the management of conflict resolution and post conflict reconstruction: South Africa, Namibia, Mozambique, Somalia, Sudan, Kenya, Uganda, Mauritius. Athens, OH: Ohio University Press. 207 p.

32. Njikam, O. (2004): Exports and economic growth in Sub-Saharan Africa: is there a Connection?' University of Yaoundé, Cameroon. Retrieved on May 26, 2018 from http://www.csae.ox.ac.uk/conferences/2004.../3 fousmanou-CSAE2004pdf.

33. Orser, B., Spence, M., Riding, A. \& Carrington, C. A. (2008): "Export Propensity and Performance: Understanding the Influence of Owner Gender" Retrieved on May, 9, 2018 from:www.teffer.uotta.ca/.../ORSER-2008GenderAndExporting.pdf.

34. Rankaduwa W. (2017): Export promotion.www.econ.utah.edu/vernengo/papers/ex. Date of access: 26 May. 2018.

35. Rankin, N., Söderbom, M. and Teal, F. (2016): "Exporting from Manufacturing Firms from sub-Saharan Africa", Journal of African Economies, 15, 4, 671-687.

36. Reid, S. D. (1981): The decision-maker and export entry and expansion. Journal of International Business Studies, 12(2), 101-112.

37. Rialp, A., Rialp, J. and Knight, G.A. (2015): 'The Phenomenon of Early Internationalizing Firms: What do we know after a Decade (1993-2003) of scientific inquiry?" International Business Review, 14, 147-66.

38. Ruzzier, M., Hisrich, R. D. and Antoncic, B. (2006): "SME Internationalisation Research: Past, Present and Future", Journal of Small Business and Enterprise Development, 13, 4, 476-497.

39. Singh, M.K.and Mahadevan, Anant. (2012): Modern Management Series: Export Management. New Delhi: Discovery Publishing House, Inc.

40. Sisay, M.A. (2018): Assessment of Challenges in Export Marketing: The Case of Ethiopian Vegetable and Fruit Commercial Growers. iBusiness, 10, 1-20.

41. Sousa, C. M. P., Martínez-López, F. J. \& Coelho, F. (2013): “The Determinants of Export Performance: A Review of the Research in the Literature between 1998 and 2005", International Journal of Management Reviews, 10, 4, 343-374.

42. UNESCAP. (2017): Introduction to export promotion. Commission for Asia and Pacific (ESCAP).http://www.unescap.org/tid/publication/tinpub2107_chap3.pdf Date of access: 11 May 2018.

43. Westhead, P., Wright, M. and Ucbasaran, D. (2008): "Internationalization of Private Firms: Environmental Turbulence and Organizational Strategies and Resources", Entrepreneurship \& Regional Development, 16, 6, 501-522.

44. Williams, D. A. (2014): "Export Stimulation of Micro- and Small Locally Owned Firms from Emerging Environments: New Evidence”, Journal of International Entrepreneurship, 6, 101-122.

45. Wolf, S. (2017): "Firm Characteristics of Non-Traditional Exporters in Ghana", The European Journal of Development Research, 19, 3, 391-411.

46. World Bank. (2018): Exports of goods and services (\% of GDP). Available online at data.worldbank.org/indicator/NE.EXP.GNFS.ZS/countries [Accessed May 28, 2018]. 
47. Yang, J. (2008): An analysis of the so called export-led growth. http://www.imf.org/external/pubs/ft/wp/2008/wp08220.pdf Date of access: 11 May 2018.

48. Zang, Wenyu and Mark Baimbridge. (2012): Exports, Imports and Economic Growth in South Korea and Japan: A Tale of Two Economies.ll Applied Economics, 44 (3): 361- 372. 